DOI: 10.14720/aas.2016.107.2.09

Agrovoc descriptors: Agaricus bisporus, Pleurotus ostreatus, edible fungi, growing media, agricultural wastes

Agris category code: F01,p35

\title{
Agronomic quantitative assessment of substrates based on spents of Agaricus bisporus and Pleurotus ostreatus
}

\author{
$\mathrm{M}^{\mathrm{a}}$ Raquel Picornell BUENDÍA ${ }^{1, *}$, Arturo Pardo GIMÉNEZ ${ }^{2}$, José Arturo de Juan VALERO ${ }^{1 \dagger}$
}

Received February 27, 2016; accepted July 04, 2016.

Delo je prispelo 27. februarja 2016, sprejeto 04. julia 2016.

\begin{abstract}
In this work the agronomic viability of substrates based on spents of Agaricus bisporus (J.E.Lange) Imbach) (SAS) and Pleurotus ostreatus (Jacq.) P. Kumm. (SPS) was studied. In addition to the commercial substrate used as reference, six different treatments were considered. In this experiment, SPS and SAS were mixed in different ratios (from $6,000 \mathrm{~g}$ and $0 \mathrm{~g}$, respectively, up to $3,000 \mathrm{~g}$ and $3,000 \mathrm{~g}$, respectively). SAS was subjected to a heat treatment in a growing room ("cook out") and then to a maturation treatment which consisted of a controlled recomposting process in growing rooms. SPS was subjected to a pasteurizing heat treatment $\left(60{ }^{\circ} \mathrm{C}-65^{\circ} \mathrm{C}, 8 \mathrm{~h}\right)$ and progressive decrease for at least $15 \mathrm{~h}$ to a "spawning" temperature $\left(25^{\circ} \mathrm{C}\right)$.

SPS $(5,400 \mathrm{~g})+$ SAS $(600 \mathrm{~g})$ and SPS $(4,800 \mathrm{~g})+$ SAS $(1,200 \mathrm{~g})$ were prepared substrates with biological efficiencies (BE) of $35.98 \%$ and $39.68 \%$ respectively, lower than the control $(46.18 \%)$ and acceptable yields. The average unit mass of fruiting body harvested was low.
\end{abstract}

Key words: agricultural wastes, edible mushrooms, Pleurotus ostreatus, quantitative parameters, spent mushroom substrates

\section{IZVLEČEK}

OVREDNOTENJE UPORABNOSTI SUBSTRATA, PRIPRAVLJENEGA IZ OSTANKOV GOJIŠČ GOJENJA DVOTROSNEGA KUKMAKA (Agaricus bisporus (J.E.Lange) Imbach) IN BUKOVEGA OSTRIGARJA (Pleurotus ostreatus (Jacq.) P. Kumm.) ZA GOJENJE BUKOVEGA OSTRIGARJA

$\mathrm{V}$ raziskavi je bila preučevana primernost ponovne uporabe ostankov gojišč, na katerih so gojili dvotrosni kukmak (Agaricus bisporus (J.E.Lange) Imbach), (SAS) in bukov ostrigar (Pleurotus ostreatus (Jacq.) P. Kumm), (SPS) kot substratov za nadaljne gojenje gob $\mathrm{v}$ primerjavi $\mathrm{S}$ komercialnimi substrati. Iz ostankov gojišč zgoraj omenjenih gob je bilo pripravljenih šest mešanic, katerih primernost je bila ovrednotena glede na komercialni substrat, ki je služil kot kontrola.V poskusu so bile pripravljene mešanice SPS in SAS $\mathrm{v}$ različnih razmerjih, od $6000 \mathrm{~g}$ in $0 \mathrm{~g}$, do $3000 \mathrm{~g}$ in $3000 \mathrm{~g}$ vsakega od substratov. SAS substrat je bil prekuhan $\mathrm{v}$ prostorih za gojenje in nato prepuščen zorjenju v procesu nadzorovanega ponovnega kompostiranja. SPS substrat je bil pasteriziran $\left(60^{\circ} \mathrm{C}-65^{\circ} \mathrm{C}, 8 \mathrm{~h}\right)$, nakar se je počasi ohlajal najmanj 15 ur do inkubacijske temperature $\left(25^{\circ} \mathrm{C}\right)$.

Mešanice SPS $(5,400 \mathrm{~g})+$ SAS $(600 \mathrm{~g})$ in SPS $(4,800 \mathrm{~g})+$ SAS $(1,200 \mathrm{~g})$ so bili primerni substrati $\mathrm{z}$ biološko učinkovitostjo (BE) $35.98 \%$ in $39.68 \%$, ki je manjša kot pri kontroli $(46.18 \%)$, a da še sprejemljiv pridelek. Povprečna masa pobranih gob je bila majhna.

Ključne besede: kmetijski odpadki, užitne gobe, Pleurotus ostreatus, kvantitativni parametri, izrabljena gojišča gob

\footnotetext{
1 School of Advanced Agricultural Engineering. Castilla - La Mancha University. Campus Universitario s/n, E02071, Albacete - Spain.

2 CIES. Mushroom Reasearch, Experimentation and Service Centre. C/Peñicas, s/n. Apartado 63. 16220 Quintanar del Rey. Cuenca. Spain.

* Corresponding author: MRaquel.Picornell@hotmail.com
} 


\section{INTRODUCTION}

The commercial production of mushrooms of the genus Pleurotus is, along with other species of edible mushroom (Agaricus bisporus (Lange) Imbach, and Lentinula edodes (Berkeley) Pegler), a modern and unique economic activity within the field of agronomy, with a remarkable presence in Spain and around the world. Approximately, $13,500 \mathrm{t}$ of this fungus is produced in Castilla - La Mancha (67\% of the national total) (Pardo et al., 2009). The mushroom growing sector in Spain generates about $5 \times 10^{5}$ tons of spent compost, while the $\mathrm{EU}$, as a whole, produces more than $3.5 \times 10^{6}$ tons (Pardo et al. 2009; Picornell et al., 2010). This lignocellulosic material called mushroom spent substrate, can be used in various fields of agriculture (animal feed (Zadrazil, 1980), amendments (Tajbakhsh et al., 2008), substrates of nurseries, nurseries, (Medina et al., 2009)), bioremediation (Faraco et al., 2009), aquaculture, vermiculture and biofuel (Pathak et al., 2009). But these uses are not enough to take advantage of the high volume generated annually, which accumulates in collection centres located in production areas of Spain. These spent substrates are potential contaminants, as well as, a waste of energy to recycling them. Bisaria et al. (1997) emphasized the importance of protein supplementation in substrates with low nitrogen content, in an organic or mineral form in small amounts. Excess nitrogen can reduce the degradability of the substrate, adversely interfering with production and biological efficiency. Shin et al. (1997) and Chang and Miles (2004) report that, possibly, supplementation with wheat bran (WB) is important to supply the needs of vitamins and other growth factors in the fungi nutrition.

The aim of this work is the agronomic quantitative assessment of substrates based on SAS and SPS. The use of the remaining spent mushroom substrate after the cultivation of $P$. ostreatus in new production cycles would be an agronomically viable alternative to using wheat straw (WS), which is currently used exclusively as a base material. If you consider the economic problems (associated with the use of this cereal farmer's byproduct and the high market price of WS, especially in drought years) using the remaining spent mushroom substrate is more beneficial. The material could be integrated through new formulations and methodologies with the benefits of lowering production costs and reducing the environmental impact of wastes largely not reused for other farming purposes.

\section{MATERIALS AND METHODS}

\subsection{Analytical methodology used for the characterization of materials}

In this experiment, the chemical characterization (moisture content, total nitrogen, protein, ash, organic matter, $\mathrm{C} / \mathrm{N}$ ratio, crude fiber, NFE, NDS, and cellulose) was studied using two different base materials in the made substrates. The characterization of raw materials and processed substrates was measured according to following parameters: moisture (MAPA, 1994), pH (Ansorena, 1994), total nitrogen (Tecator, 1987; MAPA, 1994), ash (MAPA, 1994), organic matter (Ansorena, 1994), C:N ratio, crude fiber (ANKOM, 2008), crude fat (ANKOM, 2009), nitrogen free extractives (NFE) (González et al., 1987), and cellulose and neutral detergent-soluble (NDS) (ANKOM, 2005; 2006a, 2006b).
Furthermore the exploration of mites (Krantz, 1986) and nematodes (Nombela and Bello, 1983) was performed.

\subsection{Preparation of substrates and experimental design}

The only agronomic factor being studied in this experiment is the type of base substrate with four block replicates. In accordance with the experimental design, seven different treatments were generated in the process, as well as two reference commercial substrates. To all the treatments, except the controls, $50 \mathrm{~g} \mathrm{~kg}^{-1} \mathrm{CaSO}_{4}$ (gypsum) was added to the base material. In varying amounts, $\mathrm{CaCO}_{3}$ was also added (Table 1). 
Table 1: Treatments tested $(\mathrm{g} / \mathrm{bag})$ in the Experiment

\begin{tabular}{cccc}
\hline TREATMENT & SPS $(\mathrm{g})$ & SAS $(\mathrm{g})$ & GYPSUM $(\mathrm{g})$ \\
\hline T1 & 6,000 & 0 & 300 \\
T2 & 5,400 & 600 & 300 \\
T3 & 4,800 & 1,200 & 300 \\
T4 & 4,200 & 1,800 & 300 \\
T5 & 3,600 & 2,400 & 300 \\
T6 & 3,000 & 3,000 & 300 \\
& & & \\
T7 & & Commercially controlled based substrates $\left(6.3 \mathrm{~kg} \mathrm{bag}^{-1}\right)$ \\
\hline
\end{tabular}

T, treatment; SPS, spent Pleurotus ostreatus substrate; SAS, spent Agaricus bisporus substrate; T7, commercial substrate

SPS (Champymar, Quintanar del Rey, Cuenca) was composed of wheat straw (fresh, maximum one week emptying rooms). Materials were mixed and the moisture content adjusted. Once this was done, a pasteurizing heat treatment $\left(60^{\circ} \mathrm{C}-65^{\circ} \mathrm{C}\right.$, $8 \mathrm{~h}$ ) was performed. Afterwards, the temperature was decreased to the "spawning" temperature $\left(25^{\circ} \mathrm{C}\right)$ over $15 \mathrm{~h}$. Finally, a supplementation and "spawning" (dose $30 \mathrm{~g} \mathrm{~kg}^{-1}$ mycelium Fungisem K15) were performed and the samples were bagged in CIES pilot plant.

All substrates were packed into transparent polyethylene bags of $29 \mathrm{~cm}$ in diameter and a height ranging from 25 to $35 \mathrm{~cm}$, according to the substrate type, totalling $6.3 \mathrm{~kg}$ approximate of mass. Four holes $2.2 \mathrm{~cm}$ in diameter were uniformly punctured over the side of the bags.

A controlled recomposting process was carried out. This consisted of a heat treatment in the growing room. Since air heats faster than the substrate, it reaches the maximum temperature $\left(71^{\circ} \mathrm{C}\right)$ in $19 \mathrm{~h}$, whereas the substrate reaches this temperature in $22 \mathrm{~h}$. After the heat treatment, the temperature is decreased. The air temperature falls more rapidly than the substrate temperature causing the second to be above the first. Finally, the temperature equilibrates to $34-38^{\circ} \mathrm{C}$ after $31 \mathrm{~h}$.

\subsection{Driving and monitoring of the crop cycle}

The total research time was 70 days. The experiment was carried out at the Center for Research, Experimentation and Mushroom Services (CIES), (Cuenca, Spain) in an experimental greenhouse with controlled temperature, substrate temperature, relative humidity, and carbon dioxide concentration and followed the recommended ranges for the variety of selected mycelium (Funginsem K-15) in each stage of development (CIES, 2007).

During recomposting and maturation the moisture content of the mass was maintained at $500 \mathrm{~g} \mathrm{~kg}^{-1}$ without leaching. In this process, the evolution of the moisture content in non-intervened composting had values ranging from $527 \mathrm{~g} \mathrm{~kg}^{-1}$ (at the beginning of the process) to $504 \mathrm{~g} \mathrm{~kg}^{-1}$ (at the end of the ripening process).

Substrate incubation was approximately 17 days (without external ventilation or lighting). During the incubation period, the relative humidity inside the greenhouse ranged between $90 \%$ and $95 \%$, while the substrate temperature was between $16{ }^{\circ} \mathrm{C}$ and $24{ }^{\circ} \mathrm{C}$. The room temperature ranged between $18{ }^{\circ} \mathrm{C}$ and $22^{\circ} \mathrm{C}$ to help control the temperature of the substrates made. After this, fruiting was induced by ventilation (to keep $\mathrm{CO}_{2}$ levels regulated between $0.28 \%$ to $0.10 \%$ ), reduction of room temperature $\left(22^{\circ} \mathrm{C}\right.$ to $\left.14{ }^{\circ} \mathrm{C}\right)$ and substrate temperature $\left(24{ }^{\circ} \mathrm{C}\right.$ to $\left.15{ }^{\circ} \mathrm{C}\right)$, humidity ( $91 \%$ to $94.50 \%$ ), and lighting. These values are similar to the microclimatic conditions recommended by other researches (Pardo et al., 2005a; García Rollán, 2007; Pardo et al., 2007; Gregori et al., 2008; López-Rodríguez et al., 2008; Gea et al., 2009; Kurt and Buyukalaca, 2010).

\subsection{Evaluation of the quantitative parameters}

Depending on the duration of spawn run time of the substrate by the mycelium (Funginsem K-15) and tested contaminations, a parameter designated as the germination index (GI) was established. The 
GI was on a scale from 0 (no invasion) to 5 (full invasion). Mushrooms were harvested daily at their optimal commercial development. The quantity of fruiting bodies arising and mushrooms harvested were tracked throughout the whole mushroom growth cycle. The quantity was determined by the number of fruit bodies that simultaneously grew from the same hole in the substrate bag. To calculate the yield of mushrooms produced daily, each bag was weighed to the nearest gram. The estimated net yield was determined by weighing the fruiting bodies after cutting the unmarketable stipe and mass loss calculated. Once fruiting occurred, the BE was calculated and expressed as a percentage of the fresh fruiting bodies over the substrate dry mass. The BE was calculated from the yield provided by each packet, taking into consideration the charge density of the substrate in the bags and their moisture content. The unit mass of Pleurotus ostreatus (gross and net), expressed in grams, was determined from the yields obtained and the quantity of fruiting bodies harvested.

The earliness was established as the time in days since the "spawning" of the substrate to the first flush harvested (weighing the daily relative production of the substrate). Similarly, a second estimation of earliness was performed considering the total harvest.

Fruiting degree was defined as the ratio between the quantity of mushrooms produced and the quantity of holes made in the bags.

Growth and nutritional value of genus Pleurotus spp. mushrooms depend mainly on the type of substrate and growing conditions (Curvetto et al., 2002), but also the treatments applied on made substrates and the growing mycelium (Pardo et al., 2005b). These considerations are valid for other edible fungi, for example, Lentinula edodes (Berkeley) Pegler ("shiitake") (Philippoussis et al., 2002; Ozcelik and Peksen, 2007).

\subsection{Statistical analysis}

To carry out the statistical analysis, two software packages were used: Statgraphics ${ }^{\circledR}$ Plus version 5.1 , and $\operatorname{SPSS}^{\circledR}$. The techniques employed were descriptive statistics, principal component analysis, variance analysis, and correlation and regression method to evaluate the data.

Differences of $P<0.05$ were considered significant. 
Table 2: Physicochemical characterization of source materials and substrates used

\begin{tabular}{|c|c|c|c|c|c|c|c|c|c|c|c|c|c|}
\hline & & $\mathrm{pH}$ & Moisture & $\begin{array}{l}\text { Total } \\
\text { nitrogen }\end{array}$ & Protein & Ash & $\begin{array}{l}\text { Organic } \\
\text { matter }\end{array}$ & $\mathrm{C} / \mathrm{N}$ ratio & $\begin{array}{l}\text { Crude } \\
\text { fiber }\end{array}$ & $\begin{array}{l}\text { Crude } \\
\text { fat }\end{array}$ & NFE & Cellulose & NDS \\
\hline $\begin{array}{l}\text { BASE } \\
\text { MATERIALS }\end{array}$ & $\begin{array}{l}\text { SPS } \\
\text { SAS }\end{array}$ & $\begin{array}{l}5.51 \\
7.78 \\
\end{array}$ & $\begin{array}{l}776.00 \\
504.00 \\
\end{array}$ & $\begin{array}{c}6.10 \\
13.40 \\
\end{array}$ & $\begin{array}{l}38.10 \\
83.80 \\
\end{array}$ & $\begin{array}{l}158.30 \\
646.00 \\
\end{array}$ & $\begin{array}{l}841.70 \\
354.00 \\
\end{array}$ & $\begin{array}{l}80.00 \\
15.30 \\
\end{array}$ & $\begin{array}{l}298.40 \\
161.00 \\
\end{array}$ & $\begin{array}{l}3.50 \\
3.20 \\
\end{array}$ & $\begin{array}{l}501.70 \\
106.10 \\
\end{array}$ & $\begin{array}{c}310.40 \\
90.50\end{array}$ & $\begin{array}{c}308.10 \\
62.70 \\
\end{array}$ \\
\hline \multirow[t]{2}{*}{$\begin{array}{l}\text { SUBSTRATES } \\
\text { MADE }\end{array}$} & $\begin{array}{l}\mathrm{T} 1 \\
\mathrm{~T} 2 \\
\mathrm{~T} 3 \\
\mathrm{~T} 4 \\
\mathrm{~T} 5 \\
\mathrm{~T} 6 \\
\mathrm{~T}\end{array}$ & $\begin{array}{l}5.88 \\
6.96 \\
7.51 \\
7.94 \\
7.85 \\
8.07 \\
8.15\end{array}$ & $\begin{array}{l}756.00 \\
742.00 \\
740.00 \\
719.00 \\
755.00 \\
725.00 \\
672.00\end{array}$ & $\begin{array}{l}6.00 \\
7.40 \\
7.10 \\
7.60 \\
7.20 \\
8.60 \\
9.60\end{array}$ & $\begin{array}{l}37.50 \\
46.30 \\
44.40 \\
47.50 \\
45.00 \\
53.80 \\
60.00\end{array}$ & $\begin{array}{l}276.60 \\
384.30 \\
388.90 \\
474.10 \\
419.90 \\
508.80 \\
143.00\end{array}$ & $\begin{array}{l}723.40 \\
615.70 \\
611.10 \\
525.90 \\
580.10 \\
491.20 \\
857.00\end{array}$ & $\begin{array}{l}69.90 \\
48.30 \\
49.90 \\
40.10 \\
46.70 \\
33.10 \\
51.80\end{array}$ & $\begin{array}{l}289.10 \\
271.60 \\
243.00 \\
239.60 \\
238.30 \\
231.00 \\
418.70\end{array}$ & $\begin{array}{l}3.00 \\
3.40 \\
3.90 \\
4.20 \\
2.70 \\
2.50 \\
5.10\end{array}$ & $\begin{array}{l}393.80 \\
294.50 \\
319.80 \\
234.60 \\
294.10 \\
204.00 \\
373.20\end{array}$ & $\begin{array}{l}293.40 \\
215.10 \\
209.10 \\
188.40 \\
185.20 \\
153.30 \\
375.80\end{array}$ & $\begin{array}{l}213.10 \\
176.30 \\
144.90 \\
125.50 \\
131.30 \\
111.80 \\
124.00\end{array}$ \\
\hline & $\begin{array}{l}\text { Average } \\
\text { CV (\%) }\end{array}$ & $\begin{array}{c}7.48 \\
10.88\end{array}$ & $\begin{array}{c}729.00 \\
3.98\end{array}$ & $\begin{array}{c}7.64 \\
15.11\end{array}$ & $\begin{array}{l}47.80 \\
15.10\end{array}$ & $\begin{array}{c}370.80 \\
33.60\end{array}$ & $\begin{array}{c}629.20 \\
19.80\end{array}$ & $\begin{array}{l}48.50 \\
23.50\end{array}$ & $\begin{array}{c}275.90 \\
24.00\end{array}$ & $\begin{array}{c}3.54 \\
26.02\end{array}$ & $\begin{array}{c}302.00 \\
22.65\end{array}$ & $\begin{array}{c}231.47 \\
33.25\end{array}$ & $\begin{array}{c}146.70 \\
24.43\end{array}$ \\
\hline
\end{tabular}

T, treatment; SPS, spent Pleurotus ostreatus (Jacq.) P. Kumm. substrate; SAS, spent Agaricus bisporus (Lange) Imbach. substrate; T1, SPS 6,000 g; T2, SPS 5,400 g + SAS $600 \mathrm{~g}$; T3, SPS 4,800 g + SAS 1,200 g; T4, SPS 4,200 g + SAS 1,800 g; T5, SPS 3,600 g + SAS 2,400 g; T6, SPS 3,000 g + SAS 3,000 g; T7, commercially controlled based substrates; $\mathrm{CV}$, coefficient of variation; NFE, nitrogen free extractives; NDS, neutral detergent-soluble. Results expressed in $\mathrm{g} \mathrm{kg}^{-1} \mathrm{dry}$ matter, except $\mathrm{pH}$, moisture (fresh matter) and $\mathrm{C} / \mathrm{N}$ ratio. 


\section{RESULTS AND DISCUSSION}

\subsection{Analytical characterization of the base materials used and the substrates made}

The chemical characteristic results of the different source materials, substrates made, and commercially controlled based substrates are shown in Table 2. It can be concluded that the final values obtained after the SAS recomposing process were adjusted to the optimum range considered for this process (Lohr et al., 1984; Szmidt, 1994; Raymond et al., 1997). Due to high concentrations of $\mathrm{P}, \mathrm{K}, \mathrm{Ca}$, and $\mathrm{Mg}$ in the cover layer (Raymond et al., 1997), a high ash (which contributes greatly to the cover layer of mineral soil), and high values of electrical conductivity (due to release of salts from the decomposed organic matter) (Stewart and Meek, 1977; Lohr et al., 1984) are observed.

The chemical characterization (moisture content, total nitrogen, protein, ash, organic matter, $\mathrm{C} / \mathrm{N}$ ratio, crude fibre, NFE, NDS, and cellulose) was studied using two different base materials in the made substrates. With increasing SAS doses, the $\mathrm{pH}$ increases to 8.07 and the ash content to $50.88 \%$. In contrast, the moisture content decreases to $72.50 \%$, organic matter to $49.12 \%$, $\mathrm{C} / \mathrm{N}$ to 33.10 , crude fiber to $23.10 \%$, NFE to $20.40 \%$, cellulose to $15.33 \%$ and NDS to $11.18 \%$.

\subsection{Principal component analysis}

The results of the experiment are presented using the Multivariate Statistical Technique of Principal Component Analysis (PCA), according to the physicochemical characterization of the substrates made (Table 3).

Total nitrogen of the tested substrates shows a negative correlation with moisture $(r=-0.895)$ and NDS $(r=-0.747)$, and a positive correlation with $\mathrm{pH} \quad(\mathrm{r}=0.786)$ and hemicellulose content $(r=0.730)$; the correlation values are lower with the $\mathrm{C} / \mathrm{N}(\mathrm{r}=-0.544)$ and crude fibre content $(r=0.548)$ and lignin $(r=0.527)$.

$\mathrm{C} / \mathrm{N}$ ratio is highly correlated with the values of NFE $(r=0.921)$ and NDS $(r=0.848)$, but not, with $\mathrm{pH}(\mathrm{r}=-0.816)$, ash content $(\mathrm{r}=-0.682)$, cellulose $(\mathrm{r}=0.649)$ and, as stated above, total nitrogen $(r=-0.544)$.
The crude fat content of the substrates has an average negative correlation with moisture $(r=$ 0.783 ) and low correlation with lignin content $(\mathrm{r}=0.590)$, ash $(\mathrm{r}=-0.604)$, hemicellulose $(r=0.648)$ and cellulose $(r=0.652)$.

As expected, the correlation between the crude fibre and ash content is high, with a negative correlation value of $r=-0.931$, and a positive value of $r=0.948$ with cellulose. When the crude fibre is correlated with hemicellulose $(r=0.831)$, moisture $(r=-0.747)$, lignin $(r=0.776)$, and crude fat $(r=0.705)$, the values are lower. This correlation decreases to $\mathrm{r}=0.660$ when considering NFE, and to $\mathrm{r}=0.548$, when considering the total nitrogen content.

Finally, the ash content correlates with a large number of analytical parameters of the processed substrates; in all cases, these correlations are negative: cellulose $(r=-0.987)$, crude fibre $(r=-$ 0.931), NFE ( $\mathrm{r}=-0.889)$, lignin (- 0.767), hemicellulose $(-0.714), \mathrm{C} / \mathrm{N}(\mathrm{r}=-0.682)$ and crude fat $(\mathrm{r}=-0.604)$. 
Table 3: Substrate analytical parameters correlation matrix

\begin{tabular}{|c|c|c|c|c|c|c|c|c|c|c|c|c|}
\hline & $\mathrm{pH}$ & & & & & & & & & & & \\
\hline $\mathrm{pH}$ & 1.000 & Moisture & & & & & & & & & & \\
\hline Moisture & $-0.601 *$ & 1.000 & Nitrogen $_{\mathrm{T}}$ & & & & & & & & & \\
\hline Nitrogen $_{\mathrm{T}}$ & $0.786^{* *}$ & $-0.895 * * *$ & 1.000 & Ash & & & & & & & & \\
\hline Ash & 0.228 & 0.484 & -0.229 & 1.000 & $\begin{array}{l}\mathrm{C} / \mathrm{N} \\
\text { ratio }\end{array}$ & & & & & & & \\
\hline $\mathrm{C} / \mathrm{N}$ ratio & $-0.816^{* *}$ & 0.252 & $-0.544^{*}$ & $-0.682 *$ & 1.000 & $\begin{array}{l}\text { Crude } \\
\text { fibre }\end{array}$ & & & & & & \\
\hline Crude fibre & 0.058 & $-0.747 * *$ & $0.548^{*}$ & $-0.931 * * *$ & 0.390 & 1.000 & $\begin{array}{l}\text { Crude } \\
\text { fat }\end{array}$ & & & & & \\
\hline Crude fat & 0.305 & $-0.783^{* *}$ & 0.490 & $-0.604 *$ & 0.097 & $0.705^{* *}$ & 1.000 & NFR & & & & \\
\hline NFE & $-0.558 *$ & -0.052 & -0.225 & $-0.889 * * *$ & $0.921 * * *$ & $0.660^{*}$ & 0.352 & 1.000 & Hemi & & & \\
\hline Hemi & 0,495 & $-0,766^{* *}$ & $0,730 * *$ & $-0,714 * *$ & 0,035 & $0,831 * *$ & 0,648 & 0,411 & 1.000 & Cellu & & \\
\hline Cellu & -0.206 & $-0.558 *$ & 0.271 & $-0.987 * * *$ & $0.649^{*}$ & $0.948 * * *$ & $0.652^{*}$ & $0.843 * *$ & $0.689^{*}$ & 1.000 & Lignin & \\
\hline Lignin & 0,319 & $-0,601 *$ & $0,527^{*}$ & $-0,767 * *$ & 0,233 & $0,776^{* *}$ & $0,590^{*}$ & $0,583^{*}$ & $0,942 * * *$ & $0,717 * *$ & 1 & NDS \\
\hline NDS & $-0.988 * * *$ & $0.545^{*}$ & $-0.747 * *$ & -0.316 & $0.848 * * *$ & 0.034 & -0.206 & $0.625^{*}$ & -0.406 & 0.287 & $-0,243$ & 1.000 \\
\hline
\end{tabular}

NFE, nitrogen free extractives; Hemi, hemicellulose; Cellu, cellulose; NDS, neutral detergent-soluble; Nitrogen ${ }_{\mathrm{T}}$, total nitrogen. $\mathrm{g}_{\mathrm{kg}}{ }^{-1} \mathrm{dry}_{\mathrm{matter}}$, except $\mathrm{pH}$, moisture (over fresh matter) and $\mathrm{C} / \mathrm{N}$ ratio.

Absolute value of the correlation coefficient between 0.50 and $0.69(*)$, from 0.70 to $0.84(* *)$ or equal to or greater than $0.85(* * *)$. 
$M^{a}$ Raquel Picornell BUENDÍA et al.

Table 4: Total variance explained by each factor.

\begin{tabular}{llll}
\hline \multirow{2}{*}{ Factor } & \multicolumn{2}{l}{ Initial eigenvalues } & \\
\cline { 2 - 4 } & Total & \% variance & \% cumulated variance \\
\hline 1 & 6.33 & 52.77 & 52.77 \\
2 & 4.58 & 38.20 & 90.97 \\
3 & 0.62 & 5.15 & 96.12 \\
4 & 0.37 & 3.09 & 99.21 \\
5 & 0.06 & 0.48 & 99.69 \\
6 & 0.04 & 0.31 & 100.00 \\
7 & 0.00 & 0.00 & 100.00 \\
- & - & - & - \\
- & - & - & - \\
12 & 0.00 & 0.00 & 100.00 \\
\hline
\end{tabular}

According to the results, there are two main factors that explain the total variance $(90.97 \%)$ of the experiment (Table 4).

Table 5: Rotated Component Matrix for analytical parameters and factors

\begin{tabular}{lll}
\hline Analytical parameter & Factor 1 & Factor 2 \\
\hline $\mathrm{pH}$ & 0.174 & $-0.962^{* * *}$ \\
Moisture & $-0.768^{* *}$ & 0.544 \\
Total nitrogen & 0.566 & $-0.768^{* *}$ \\
Ash & $-0.915^{* * *}$ & -0.397 \\
$\mathrm{C} / \mathrm{N}$ ratio & 0.346 & $0.929 * * *$ \\
Crude fibre & $0.971 * * *$ & 0.078 \\
Crude fat & $0.779 * *$ & -0.181 \\
NFE & 0.657 & $0.732 * *$ \\
Hemicellulose & $0,905 * * *$ & $-0,303$ \\
Cellulose & $0.920^{* * *}$ & 0.358 \\
Lignin & $0,885^{* * *}$ & $-0,104$ \\
NDS & -0.080 & $0.971 * * *$ \\
\hline
\end{tabular}

NFE, nitrogen free extractives; NDS, neutral detergent-soluble.

Extraction method: principal component analysis; rotation method: Varimax Normalization with Kaiser; the rotation converged in 5 iterations.

Extent of participation, in absolute value, between 0.70 and $0.84(* *)$ or equal to or greater than $0.85(* * *)$.

In Table 5 the "Rotated Component Matrix" for analytical parameters and experiment factors are given. The variables: ash, crude fibre, hemicellulose, cellulose, and lignin content of the substrates are those with a higher degree of participation in shaping this first factor, with factor values of $-0.915,0.971,0.905,0.920$ and 0.885 , respectively. The mean values of participation in the Factor 1 are expressed with moisture and crude fat, with load factor values of -0.768 and 0.779 , respectively. Factor 2 is defined by $\mathrm{pH}, \mathrm{C} / \mathrm{N}$ and NDS with a load factor of - 0.962, 0.929 and 0.971 , respectively; the average values of participation in the Factor 2 are manifested in total nitrogen and NFE, with values of load factor 0.768 and 0.732 , respectively. 
Table 6: ANOVA of substrate germination index

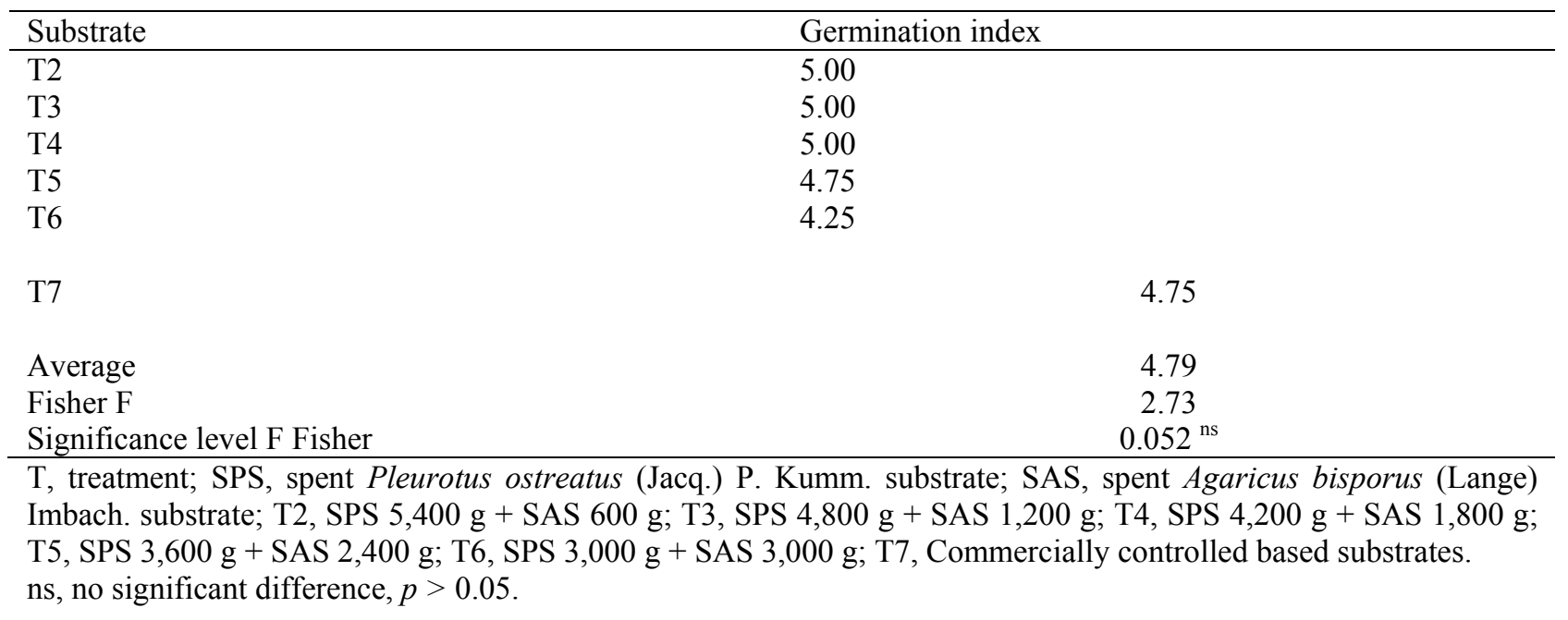

\subsection{Germination rate. Descriptive statistics and analysis of variance}

In Table 6 the results obtained for the GI of evaluated substrates are given. In this experiment, we obtained up to three flushes, the same as those achieved by Pardo and Lopez Mondéjar (2004). Mata and Gaitán-Hernádez (1995) and Salmones et al. (1997), also, obtained four harvests crops in their experiments. As in the experiments conducted by Bonilla-Lavado et al. (2006), where the production of $P$. ostreatus had four flushes (in the third flush, all treatments were productive although at a lower rate than the first two flushes, which only enriched Tithonia diversifolia (Hemsl.)), coinciding with the studies by Lozano (1990), who obtained harvests for two months. Gea et al. (2009) reported, on experiments based on P. ostreatus, a first flush, lasting approximately 10 days, from which primordia was formed constantly and uninterrupted, for more than a month, until the end of the trial; therefore, a clearly defined second flush was not necessary. Bernabé-González et al. (2004), evaluated three flushes of $P$. pulmonarius (Fr.) Quél., which were unstable, except in dry jicama stover where only two flushes occured. Philippoussis et al. (2001) achieved the same flushes with $P$. ostreatus, $P$. pulmonarius and Pleurotus eryngii (DC.) Quél.. In general, and in the present study, the higher yields were obtained between the first and second flush (80 to $90 \%$ of total production), except Zeng-Chin et al. (2009) who through growing of $P$. citrinopileatus Singer, achieved five flushes and obtained higher $\mathrm{BE}$ in the second flush.

Of the six different treatments that have been generated with different mixtures, treatment 1 , consisting of $6,000 \mathrm{~g}$ of SPS, showed difficulties in germination and a high degree of contamination by Gliocladium spp. (which can be associated to the low $\mathrm{pH}$ of the substrate (Table 2)), which produced difficulties in mycelial development, growth arrest, and the absence of production of Pleurotus ostreatus. In the rest of the processed substrates, GI was adequate, and was found that the two treatments with lower SAS were the earliest in the first flush (difference that was cancelled when the earliness referred to days from inoculation to full induction).

The substrates of T2, T3 and T4 have the highest GI (5.00), higher than the average of the 24 substrates (4.79). The substrates of $\mathrm{T} 5$ and $\mathrm{T} 7$ (commercial) have a GI of 4.75 , and the substrate with the GI lowest is T6 (4.25).

\subsection{Quantitative production parameters. Descriptive statistics and analysis of variance}

The most noteworthy aspects according to quantitative production parameters are presented in Table 7. The duration of the commercial crop cycle was 70 days, 16 of which were for the incubation period. 
Table 7: ANOVA of the quantitative parameters of the Experiment

\begin{tabular}{|c|c|c|c|c|c|c|c|}
\hline \multirow[b]{2}{*}{ Substrate } & \multicolumn{2}{|c|}{ Earliness (days) } & \multirow[b]{2}{*}{$\begin{array}{l}\text { Gross yield } \\
\left(\mathrm{g} \mathrm{bag}^{-1}\right)\end{array}$} & \multirow{2}{*}{$\begin{array}{l}\text { Index } \\
\text { fructification } \\
\text { Number } \\
\text { fruit.bodies } \\
\text { hole }^{-1} \\
\end{array}$} & \multirow[b]{2}{*}{$\begin{array}{l}\text { Number } \\
\text { mushrooms bag }{ }^{-1}\end{array}$} & \multirow[b]{2}{*}{ UM } & \multirow[t]{2}{*}{$\mathrm{BE}$} \\
\hline & $\begin{array}{l}1^{\text {st }} \quad \text { Flush } \\
\text { "spawning" }\end{array}$ & $\begin{array}{l}\text { Total } \\
\text { "spawning" }\end{array}$ & & & & & \\
\hline $\mathrm{T} 2$ & $23.40 \mathrm{~cd}$ & $35.93 b$ & $573.75 \mathrm{bc}$ & 1.19 & $49.00 \mathrm{ab}$ & $8.95 b$ & $35.98 \mathrm{ab}$ \\
\hline $\mathrm{T} 3$ & $21.35 d$ & $33.13 b$ & $637.50 \mathrm{ab}$ & 1.19 & $63.00 \mathrm{a}$ & $7.50 \mathrm{~b}$ & $39.68 \mathrm{ab}$ \\
\hline $\mathrm{T} 4$ & $28.15 b c$ & $33.85 b$ & $472.50 \mathrm{bc}$ & 1.00 & $34.75 b c$ & $10.79 b$ & $27.23 b c$ \\
\hline $\mathrm{T} 5$ & $30.23 b$ & $35.18 b$ & $341.75 b c$ & 0.69 & $22.75 b c$ & $11.89 \mathrm{ab}$ & $22.58 b c$ \\
\hline T6 & $32.55 \mathrm{ab}$ & $39.15 \mathrm{ab}$ & $260.75 c$ & 0.69 & $19.25 \mathrm{c}$ & $10.92 b$ & $15.88 \mathrm{c}$ \\
\hline $\mathrm{T} 7$ & $36.73 a$ & $43.80 \mathrm{a}$ & $938.75 a$ & 1.00 & $41.50 \mathrm{abc}$ & $19.54 \mathrm{a}$ & $46.18 \mathrm{a}$ \\
\hline Average & 28.73 & 36.84 & 537.50 & 0.96 & 38.37 & 11.60 & 31.25 \\
\hline Fisher $\mathrm{F}$ & 16.24 & 6.01 & 9.61 & 2.56 & 7.00 & 4.91 & 8.19 \\
\hline $\mathrm{S}_{\mathrm{L}}$ & $0.00 * * *$ & $0.002 * *$ & $0.00 * * *$ & $0.06 \mathrm{~ns}$ & $0.001 * * *$ & $0.005 * *$ & $0.00 * * *$ \\
\hline
\end{tabular}

T, treatment; SPS, spent Pleurotus ostreatus (Jacq.) P. Kumm. substrate; SAS, spent Agaricus bisporus (Lange) Imbach. substrate; T2, SPS 5,400 g + SAS $600 \mathrm{~g}$; T3, SPS 4,800 g + SAS 1,200 g; T4, SPS 4,200 g + SAS 1,800 g; T5, SPS 3,600 g + SAS 2,400 g; T6, SPS 3,000 g + SAS 3,000 g; T7, commercially controlled based substrates; UM, unit mass of uncut mushrooms $(\mathrm{g})$; BE, biological efficiency $\left(\mathrm{kg} / 100 \mathrm{~kg}\right.$ of dry substrate); $\mathrm{S}_{\mathrm{L}}, \mathrm{F}$ significance level Fisher.

ns, no significant difference, $P>0.05$; ** $\mathrm{P}$-value $<0,01 ; * * * \mathrm{P}$-value $<0,001$. For each column, values followed by different letters are significantly different from each other $(\mathrm{P}=0.05$, Tukey-HSD).

According to Patra and Pani (1995) and Sánchez et al. (2006), the quality production of a substrate is acceptable from $\mathrm{BE}$ of $50 \%$. In this experiment reduction of $\mathrm{BE}$ was observed as the percentage share of SAS in prepared substrate increased (up to $15.88 \%$ ). In the observed differences among treatments comprised of different mixtures, the SAS could have worsened some physical characteristics of the substrate such as aeration and drainage, as its particles are much smaller with respect to the SPS. This may have reduced porosity in the substrate and increased compaction in treatments with higher rate of SAS; reducing mycelium growth. Air exchange was especially difficult due to closed bags, favouring increases in $\mathrm{CO}_{2}$ concentrations and decrease of $\mathrm{O}_{2}$ within the substrates. It can be seen that in the substrates with lower SAS content, mycelial colonization occurred in the centre of the bag, whereas in the substrates which contained higher SAS content, the fungus colonized a few centimetres of depth only.
T2 (SPS 5,400 g + SAS $600 \mathrm{~g}$ ) and T3 substrates (SPS 4,800 g + SAS 1,200 g), provided acceptable yields, with BE values of $35.98 \%$ and $39.68 \%$, respectively, lower than the control $(46.18 \%)$ (Table 7). Several authors have succeeded in studying the growth of $P$. ostreatus with different types of substrates resulting in higher $\mathrm{BE}$ values than those obtained in this experiment with BE values up to $125 \%$ (Klibanski et al., 1993; GaitánHernádez and Salmones, 1996), up to $138 \%$ with $P$. pulmonarius on coffee pulp (Velázquez-Cedeño et al., 2002), and up to $164 \%$ on mixtures of jicama stover and corn stover (Bernabé-González et al., 2004). BE is mainly determined by Pleurotus spp. species and the type of substrate used. BE increases when the substrates are enriched with nutrients of natural or synthetic origin (Bonilla-Lavado et al., 2006); these researchers, in their experiments, obtained between $0.60 \%$ (on coir) and $36.40 \%$ (on sawdust mixture and Tithonia diversifolia (Hemsl.) A.Gray). Pardo et al. (2003), working with straw, vine shoot, kenaf, and various combinations of these raw 
materials, obtained $\mathrm{BE}$ values ranging between 6.75 and $14.02 \%$. In a later work, Pardo et al. (2005b) only achieved values of 23.00 and $26.90 \%$ when they combined winter cereal straw and kenaf and then subjected the substrate to pasteurization and thermophilic conditioning. Perez and Mata (2005) with P. ostreatus obtained $\mathrm{BE}$ values of $28.10 \%$ based on pine shavings.

Salmones et al. (1997) obtained BE ranging between $16.80 \%$ and $71.90 \%$, using barley straw substrate. Guzman et al. (2003) obtained BE in $P$. ostreatus up to $59.00 \%$ with waste sugarcane. Garzón and Cuervo (2008) in their research show how wood sawdust and corn stalk BE are improved up to values of $29.10 \%$ to $48.40 \%$ when they are combined with coffee pulp and bagasse sugarcane in different proportions. Varnero et al. (2010) obtained BE values of $2.97 \%$ on poplar chips and $32.94 \%$ on wheat straw. According to the results obtained in this work and those offered by the literature, low BE values are observed when the degree of participation in the prepared substrate SAS is greater; due to the prepared substrates not receiving nutritional supplementation.

Pardo et al. (2005b), working with various substrates made different combinations of WS, barley straw, kenaf, vine-and grape seed flour. The total quantity of mushrooms bag ${ }^{-1}$ obtained varied between 42 and 82 , with the lowest yields of 20.50 $\mathrm{g}$ and $32.70 \mathrm{~g}$ on combination of straw and kenaf. While the first yield component value is less than the values obtained in this experiment (19.25 to 63 mushrooms), the average unit mass is much higher (between 7.50 and $11.89 \mathrm{~g}$, excluding the one offered by the commercial substrate which was $19.54 \mathrm{~g}$ ) (Table 7). In another work of Pardo et al. (2005a) where scrape, straw, kenaf, vine shoot and "alperujo" were combined the average mass of an upper part of the mushroom ranged between $12 \mathrm{~g}$ and $93 \mathrm{~g}$. However, the number of fruiting bodies hole $^{-1}$ ranged between 0.02 and 1 , in general and was lower compared to results of this experiment 0.69 and 1.19 (Table 7). Using pasteurization and thermophilic conditioning treatments, benomyl moisturization and pasteurization, and semianaerobia fermentation with the same substrates in the same bags, Pardo et al. (2007) obtained average mushroom upper part mass ranging between 14.60 and $25.90 \mathrm{~g}$ (higher than those presented in Table 7).

Gea et al. (2009), using parallelepipedic packages with 7 holes of $25 \mathrm{~mm}$ in diameter and a specific substrate for $P$. ostreatus cultivation which separates supplements made from aerobic fermentation, achieved a range of 88 to 136 mushrooms bag ${ }^{-1}$ and an average fruiting body mass of $12.40 \mathrm{~g}$ to $14.50 \mathrm{~g}$ (each values higher than those presented in Table 7). This research offered fruiting index values between 1.21 and 1.57 fruiting bodies per hole. As is the case in this experiment, the literature confirms that increasing the quantity of fruiting bodies per hole and the quantity of mushrooms per bag, decreases the value of a mushroom mass.

$\mathrm{T} 1$, consisting of $6,000 \mathrm{~g}$ of SPS, showed difficulties in germination and a high degree of contamination by Gliocladium spp. Due to these reasons, T1 was not included in the statistical analysis of this experiment.

\subsection{Correlation matrix and "step by step" regression models}

Table 8 presents the correlation matrix between GI, earliness, quantitative production parameters, and physicochemical characteristics of the substrates made. With statistical significance, the cellulose content has positively favoured both the GI and the $\mathrm{BE}(\mathrm{r}=0.913$ and $\mathrm{r}=0.948$, respectively) and negatively days from inoculation until the formation of the first primordia $(r=-0.922)$ (Table 8). Although not statistically significant $(\mathrm{P}=8.2 \%)$ a high positive correlation was found between $\mathrm{C} / \mathrm{N}$ and $\mathrm{BE}(\mathrm{r}=0.830)$ and negative with ash content $(\mathrm{P}=7.2 \% ; \mathrm{r}=-0.844)$. Also, the number of yield component of mushrooms $(\mathrm{r}=0.854)$ with the cellulose content was positively correlated, but without statistical significance $(\mathrm{P}=6.6 \%)$. 
Table 8: Correlation matrix between germination index, earliness, and production of quantitative parameters, and physicochemical characteristics.

\begin{tabular}{|c|c|c|c|c|c|c|}
\hline & $\begin{array}{l}\text { Germination } \\
\text { Index }\end{array}$ & $\begin{array}{l}1^{\text {st }} \text { Flush } \\
\text { "spawning" }\end{array}$ & $\begin{array}{c}\text { Total } \\
\text { "spawning" }\end{array}$ & $\begin{array}{l}\text { Total quantity } \\
\text { of mushrooms }\end{array}$ & UM & $\mathrm{BE}$ \\
\hline \multirow{2}{*}{$\mathrm{pH}$} & -0.600 & 0.789 & 0.247 & -0.703 & 0.659 & -0.784 \\
\hline & $(0.284)$ & $(0.113)$ & $(0.689)$ & $(0.186)$ & $(0.227)$ & $(0.117)$ \\
\hline \multirow{2}{*}{$\operatorname{Nitrogen}_{\mathrm{T}}^{1}$} & -0.854 & 0.695 & 0.864 & -0.621 & 0.384 & -0.743 \\
\hline & $(0.065)$ & $(0.193)$ & $(0.059)$ & $(0.263)$ & $(0.524)$ & $(0.150)$ \\
\hline \multirow{2}{*}{ Ash } & -0.722 & 0.832 & 0.582 & -0.749 & 0.622 & -0.844 \\
\hline & $(0.168)$ & $(0.080)$ & $(0.304)$ & $(0.145)$ & $(0.263)$ & $(0.072)$ \\
\hline \multirow{2}{*}{$\mathrm{C} / \mathrm{N}$ ratio } & 0.784 & -0.805 & -0.712 & 0.726 & -0.556 & 0.830 \\
\hline & $(0.116)$ & $(0.100)$ & $(0.177)$ & $(0.165)$ & $(0.331)$ & $(0.082)$ \\
\hline \multirow{2}{*}{ Crude fibre $^{1}$} & 0.582 & -0.648 & -0.163 & 0.545 & -0.478 & 0.657 \\
\hline & $(0.304)$ & $(0.237)$ & $(0.793)$ & $(0.343)$ & $(0.415)$ & $(0.228)$ \\
\hline \multirow{2}{*}{ Crude fat ${ }^{1}$} & 0.822 & -0.662 & -0.809 & 0.693 & -0.533 & 0.700 \\
\hline & $(0.088)$ & $(0.223)$ & $(0.098)$ & $(0.195)$ & $(0.355)$ & $(0.189)$ \\
\hline \multirow{2}{*}{$\mathrm{NFE}^{1}$} & 0.683 & -0.776 & -0.661 & 0.709 & -0.570 & 0.789 \\
\hline & $(0.204)$ & $(0.123)$ & $(0.225)$ & $(0.180)$ & $(0.315)$ & $(0.112)$ \\
\hline \multirow{2}{*}{ Cellulose $^{1}$} & $0.913^{*}$ & $-0.922 *$ & -0.721 & 0.854 & -0.690 & $0.948 * *$ \\
\hline & $(0.031)$ & $(0.026)$ & $(0.170)$ & $(0.066)$ & $(0.197)$ & $(0.014)$ \\
\hline \multirow{2}{*}{$\mathrm{NDS}^{1}$} & 0.666 & -0.782 & -0.317 & 0.684 & -0.603 & 0.788 \\
\hline & $(0.220)$ & $(0.118)$ & $(0.603)$ & $(0.203)$ & $(0.281)$ & $(0.113)$ \\
\hline
\end{tabular}

$\overline{\mathrm{UM}}$, unit mass of uncut mushrooms $(\mathrm{g})$; BE, biological efficiency; Nitrogen ${ }_{\mathrm{T}}$, total nitrogen; NFE, nitrogen free extractives; NDS, neutral detergent-soluble; ${ }^{1}, \mathrm{~g} \mathrm{~kg}^{-1}$ dry matter.

Results in parentheses indicate statistical significance. No significant $(P>0.05)$ (non *); significant at $95 \%(0.01<$ $P \leq 0.05)(*)$; significant at $99 \%(0.001<P \leq 0.01)(* *)$.

The highest cellulose content in the previously mentioned mixtures favoured the fruition of oyster mushroom (number of flushes, total yield and BE) due to a higher SPS content. The opposite occurred in the time period between inoculation and the appearance of the first primordia. Although not significant from the statistical point of view, higher $\mathrm{C} / \mathrm{N}$ ratios have also favoured $\mathrm{BE}$, but not the higher total nitrogen contents. Several researches have shown that low nitrogen contents can be a depressive factor for growing of many edible mushrooms (Boyle, 1998; Philippoussis et al., 2002 , 2003). The quantity of mushrooms is positively correlated with the $\mathrm{BE}$ in this experiment $(r=0.975)$, while the correlation is negative with the second yield component, unit mass $(\mathrm{r}=-0.952)$. This last yield component, although not significant, is negatively correlated with the $\mathrm{BE}(\mathrm{P}=5.40 \% ; \mathrm{r}=-0.872)$ (Table 9$)$. 
Table 9: Correlation matrix between the rate of germination, earliness, yield components, and biological efficiency.

\begin{tabular}{|c|c|c|c|c|c|c|}
\hline & $\begin{array}{l}\text { Germination } \\
\text { Index }\end{array}$ & & & & & \\
\hline $\begin{array}{l}\text { Germination } \\
\text { Index }\end{array}$ & 1.000 & $\begin{array}{c}1^{\text {rs }} \text { Flush } \\
\text { "spawning", }\end{array}$ & & & & \\
\hline $\begin{array}{c}1^{\mathrm{rs}} \text { Flush } \\
\text { "spawning" }\end{array}$ & $\begin{array}{l}-0.793 \\
(0.109)\end{array}$ & 1.000 & $\begin{array}{c}\text { Total } \\
\text { "spawning" }\end{array}$ & & & \\
\hline $\begin{array}{c}\text { Total } \\
\text { "spawning" }\end{array}$ & $\begin{array}{c}-0.887^{*} \\
(0.045)\end{array}$ & $\begin{array}{c}0.667 \\
(0.219)\end{array}$ & 1.000 & $\begin{array}{l}\text { Total quantity } \\
\text { of mushrooms }\end{array}$ & & \\
\hline $\begin{array}{l}\text { Total quantity of } \\
\text { mushrooms }\end{array}$ & $\begin{array}{c}0.738 \\
(0.154)\end{array}$ & $\begin{array}{c}-0.987 * * \\
(0.002)\end{array}$ & $\begin{array}{l}-0.658 \\
(0.228)\end{array}$ & 1.000 & UM & \\
\hline UM & $\begin{array}{l}-0.502 \\
(0.389)\end{array}$ & $\begin{array}{l}0.912 * \\
(0.031)\end{array}$ & $\begin{array}{c}0.420 \\
(0.481)\end{array}$ & $\begin{array}{c}-0.952 * * \\
(0.013)\end{array}$ & 1.000 & $\mathrm{BE}$ \\
\hline $\mathrm{BE}$ & $\begin{array}{c}0.847 \\
(0.070)\end{array}$ & $\begin{array}{c}-0.996^{* * *} \\
(0.000)\end{array}$ & $\begin{array}{l}-0.720 \\
(0.170)\end{array}$ & $\begin{array}{c}0.975 * * \\
(0.005)\end{array}$ & $\begin{array}{l}-0.872 \\
(0.054)\end{array}$ & 1.000 \\
\hline
\end{tabular}

UM, unit mass of uncut mushrooms (g); BE, biological efficiency (kg/100 kg of dry substrate).

Results in parentheses indicate statistical significance. Not significant $(P>0.05)$ (non *); significant at $95 \%(0.01<$ $P \leq 0.05)(*)$; significant at $99 \%(0.001<P \leq 0.01)(* *) ; 99.9 \%$ significant $(P \leq 0.001)(* * *)$.

Table 10 shows the "step by step" regression analysis to the physical - chemical properties of substrates, GI, earliness, and quantitative production parameters of the current experiment. Cellulose explains a high percentage of variability in both GI and number of days from inoculation until the formation of the first primordia, although in the first case, there is a positive coefficient and in the second, the coefficient accompanying the model is negative. GI, in turn, is involved in the mathematical model explaining the variability of the days from inoculation until full induction, but the coefficient accompanying the model is negative. With a high fit value, the model which explains the variability of yield component, quantity of mushrooms, includes a negative coefficient for the days from inoculation until the appearance of the first primordia. The other yield component, average unit mass of mushrooms, is well explained with a negative coefficient for the quantity of mushrooms. Finally, the $\mathrm{BE}$ is explained by a model including, with positive coefficients, the quantity of mushrooms and the cellulose content of made substrates. The days from inoculation until the appearance of the first primordia have a negative correlation with a high determination coefficient value for BE. 
Table 10: Models obtained by regressing "step by step".

\begin{tabular}{|c|c|c|c|c|}
\hline $\begin{array}{l}\text { Explained } \\
\text { variable }\end{array}$ & $\begin{array}{l}\text { Independent } \\
\text { variable }\end{array}$ & Equation & $\begin{array}{l}\mathrm{R}^{2} \\
\text { corrected }\end{array}$ & $\mathrm{SE}$ \\
\hline GI & PCC & $\mathrm{GI}=2.474 *+0.012 * \cdot \mathrm{C}$ & $77.70^{*}$ & 0.15390 \\
\hline $\mathrm{P} 2$ & $\mathrm{PCC}+\mathrm{GI}$ & $\mathrm{P} 2=60.844^{* *}-0.177^{*} \cdot \mathrm{C}$ & $80.10^{*}$ & 2.08320 \\
\hline $\mathrm{P} 4$ & $\mathrm{PCC}+\mathrm{GI}+\mathrm{P} 2$ & $\mathrm{P} 4=66.049^{* *}-6.375^{*} \cdot \mathrm{GI}$ & $71.70 *$ & 1.24657 \\
\hline TQM & $\begin{array}{l}\mathrm{PCC}+\mathrm{QPP} \\
(-\mathrm{BE})\end{array}$ & $\begin{array}{l}\mathrm{N}^{\mathrm{o}} \text { mushrooms }=142.673 * * *- \\
3.867 * * \cdot \mathrm{P} 2\end{array}$ & $96.60 * *$ & 3.39052 \\
\hline UM & $\begin{array}{l}\mathrm{PCC}+\mathrm{QPP} \\
(-\mathrm{BE})\end{array}$ & $\mathrm{UM}=13.465^{* * *}-0.092^{* *} \cdot \mathrm{TQM}$ & $87.50 * *$ & 0.62358 \\
\hline \multirow{2}{*}{$\mathrm{BE}$} & $\mathrm{PCC}+\mathrm{QPP}$ & $\begin{array}{l}\mathrm{BE}=84.364 * * *-2.067 * * * \cdot \mathrm{P} 2 \\
\mathrm{BE}=55.457 * *-1.813 * * * \cdot \mathrm{P} 2+ \\
4.587 * * \cdot \mathrm{GI}\end{array}$ & $\begin{array}{l}98.80 * * * \\
100.00 * * *\end{array}$ & $\begin{array}{l}1.05719 \\
0.14023\end{array}$ \\
\hline & $\begin{array}{l}\mathrm{PCC}+\mathrm{P} 4+\mathrm{UM} \\
+\mathrm{TQM}\end{array}$ & $\begin{array}{l}\mathrm{BE}=-16.380^{* *}+0.323 * * * \cdot \mathrm{TQM} \\
+0.171 * * \cdot \mathrm{C}\end{array}$ & $99.90 * * *$ & 0.22397 \\
\hline
\end{tabular}

$\mathrm{C}$, cellulose; TQM, Total quantity of mushrooms; $\mathrm{R}^{2}$, determination coefficient (\%); SE, standard error of the estimate.

Physical-chemical characteristics of substrate (PCC): $\mathrm{pH}$ (aq. 1:5, w/w), total nitrogen $\left(\mathrm{g} \mathrm{kg}^{-1}\right.$, odm), ash ( $\mathrm{g} \mathrm{kg}^{-1}$, odm), $\mathrm{C} / \mathrm{N}$ ratio, crude fibre (CFi; $\mathrm{g} \mathrm{kg}^{-1}$, odm), crude fat (CFa; $\mathrm{g} \mathrm{kg}^{-1}$, odm), nitrogen free extractives (NFE; $\mathrm{g} \mathrm{kg}^{-1}$, odm), hemicellulose ( $\mathrm{g} \mathrm{kg}^{-1}$, odm), cellulose $\left(\mathrm{g} \mathrm{kg}^{-1}\right.$, odm), lignin (g kg-1, odm), neutral-detergent soluble (NDS; $\mathrm{g} \mathrm{kg}^{-1}$, odm); odm = on dry matter.

Index germination, earliness and quantitative production parameters (QPP): germination index (GI), days from inoculation to the formation of the first primordia ( $\mathrm{P} 2)$, days from inoculation to the onset of harvest (P4), total quantity of mushrooms, average unit mass of uncut mushrooms (UM, g), biological efficiency (BE, $\mathrm{kg} / 100 \mathrm{~kg}$ of dry substrate).

Significant at $95 \%(0,01<P \leq 0,05)(*) ; 99 \%$ $(0.001<P \leq 0.01) \quad(* *) ; 99.9 \%$ significant $(P \leq 0.001)(* * *)$. Regressions include only those whose coefficients accompanying the independent variables are significant, provided that the significance of the model is significant.

\section{CONCLUSIONS}

According to the results obtained for the combinations tested, the biological efficiencies achieved on tested substrates are lower than those obtained with the commercial reference substrate, so initially, there would be a lack of interest in the spent Pleurotus ostreatus and Agaricus bisporus substrates. However, since they are waste materials, they can be obtained with no or little money. Following treatments showed the highest
BE (35.98\% and $39.68 \%$, respectivelly) - 5,400 g SPS + $600 \mathrm{~g} \mathrm{SAS}$ and 4,800 g SPS + 1,200 g SAS, compared to $46.18 \%$ of the commercial substrate.

Consequently substrate formulations based on spent Pleurotus ostreatus and Agaricus bisporus composts could be a low-cost substrate with selective and balanced nutrients for growth and development of oyster mushrooms. 


\section{REFERENCES}

ANKOM (2005). Method for Determining Acid Detergent Lignin in Beakers. ANKOM Technology Method AK 8/05. Macedon, NY, USA.

ANKOM (2006a). Neutral Detergent Fiber in Feeds. Filter Bag Technique. ANKOM Technology Method 6. Macedon, NY, USA.

ANKOM (2006b). Acid Detergent Fiber in Feeds. Filter Bag Technique. ANKOM Technology Method 5. Macedon, NY, USA.

ANKOM (2008). Crude Fiber Analysis in Feeds By Filter Bag Technique. AOCS Approved Procedure Ba 6a-05, ANKOM Technology Method 7. Macedon, NY, USA.

ANKOM (2009). Rapid Determination of Oil/Fat Utilizing High Temperature Solvent Extraction. ANKOM Technology Method 2, AOCS Official Procedure Am 5-04. Macedon, NY, USA.

Ansorena, J. (1994). Sustratos. Propiedades y Caracterización. Ed. Mundi-Prensa, S.A., Madrid, España.

Bernabé-González, T., Cayetano-Catarino, M., AdánDíaz, A. \& Torres-Pastrana, M.A. (2004). Cultivo de Pleurotus pulmonarius sobre diversos subproductos agrícolas de Guerrero, México. Rev Mex Mic 18: 77-80.

Bisaria, R., Madan, M. \& Vasudevan, P. (1997). Utilization of agro-residues as animal feed through bioconversion. Bioresour Technol 59: 5-8. Doi: 10.1016/S0960-8524(96)00140-X

Bonilla-Lavado, H.A., Vásquez-Acosta, N.B. \& Rubiano-Rodríguez, J.A. (2006). Evaluación de residuos orgánicos (coco y aserrín) como sustratos para la producción de Pleurotus ostreatus (Jacq: Fr.) en Buenaventura. Rev Institucional Univ Tecnológica del Chocó D. L. C. 24: 54-59.

Boyle, C.D. (1998). Nutritional factors limiting the growth of Lentinula edodes and other white-rot fungi in wood. Soil Biol Biochem 30: 817-823. Doi: 10.1016/S0038-0717(97)00159-4

Chang, S.T. \& Miles, P. (2004). Mushrooms. Cultivation, Nutritional Value, Medicinal Effect, and Environmental Impact. CRC Press, Boca Ratón, FL, USA. Doi: 10.1201/9780203492086

CIES (2007). Relación de variedades comerciales de setas Pleurotus y otros hongos exóticos. En: Diputación Provincial de Cuenca (Eds.), El Champiñón en Castilla - La Mancha. Boletín informativo 25. Centro de Investigación,
Experimentación y Servicios del Champiñón, Quintanar del Rey, Cuenca, España.

Curvetto, N.R., Figlas, D., Devalis, R. \& Delmastro, S. (2002). Growth and productivity of different Pleurotus ostreatus strains on sunflower seed hulls supplemented with $\mathrm{N}^{-\mathrm{NH}_{4}}{ }^{+}$and/or $\mathrm{Mn}(\mathrm{II})$. Bioresour Technol 84: 171-176. Doi: 10.1016/S0960-8524(02)00013-5

Faraco, V., Pezzella, C., Miele, A., Giardina, P. \& Sannia, G. (2009). Bio-remediation of colored industrial wastewaters by the white-rot fungi Phanerochaete chrysosporium and Pleurotus ostreatus and their enzymes. Biodegradation 20: 209-220. Doi: 10.1007/s10532-008-9214-2

Gaitán-Hernández, R. \& Salmones, D. (1996). Cultivo y selección de cepas de Pleurotus spp., con alto rendimiento. Rev Mex Mic 12:107-113.

García Rollán, M. (2007). Cultivo de Setas y Trufas. Quinta Edición. Mundi - Prensa, S. A., Madrid, España.

Garzón, J.P. \& Cuervo, J.L. (2008). Producción de Pleurotus ostreatus sobre residuos sólidos lignocelulósicos de diferente procedencia. Nova Publicación Científica en Ciencias Biomédicas 6: 101-236.

Gea, F.J., Martínez-Carrasco, A. \& Navarro, M.J. (2009). Efecto de la suplementación del sustrato sobre la cosecha de setas. Hort Inter 67: 32-40.

González, J., Alvira, P., González, G. (1987). La cascarilla de arroz en la alimentación animal. II Composición químico-bromatológica. Rev Agroquim Tecnol 27: 139-149.

Gregori, A., Svagelj, M., Pahor, B., Berovic, M. \& Pohleven, F. (2008). The use of spent brewery grains for Pleurotus ostreatus cultivation and enzyme production. N Biotechnol 25: 157-161. Doi: 10.1016/j.nbt.2008.08.003

Guzmán, M.L., Suárez, L., Rivas, A.C. \& Sánchez, J.C.A. (2003). Producción de hongos comestibles en residuos de la caña de azúcar. Memorias VI Congreso Colombiana de la Asociación de Técnicos de la Caña de azúcar, 323 - 331. VI Congreso Colombiana de la Asociación de Técnicos de la Caña de Azúcar Ponencia.

Klibansky, M.M., Mansur, M., Gutierrez, I. \& González, L. (1993). Production of Pleurotus ostreatus mushrooms on sugar cane agrowastes. Acta Biotechnol 13: 71-78. Doi: 10.1002/abio.370130115 
Krantz, G.W. (1986). A Manual of Acarology, $2^{\text {nd }}$ Ed. Oregon St. Univ. Book Stores, Inc., Corvallis, OR, USA.

Kurt, S. \& Buyukalaca, S. (2010). Yield performances and changes in enzyme activities of Pleurotus spp. (P. ostreatus and P. sajor-caju) cultivated on different agricultural wastes. Bioresour Technol 101: 3.164-3.169.

Lohr, V.L., Wang, S.H. \& Wolt, J.D. (1984). Physical and chemical characteristics of fresh and aged spent mushroom compost. HortScience 19: 681-683.

López-Rodríguez, C., Hernández-Corredor, R., SuárezFranco, C. \& Borrero, M. (2008). Evaluación del crecimiento y producción de Pleurotus ostreatus sobre diferentes residuos agroindustriales del Departamento de Cundinamarca, Universitas Scientiarum 13: 128-137.

Lozano, J.C. (1990). Producción comercial del champiñón Pleurotus ostreatus en pulpa de café. Fitopatol Colomb 14: 42-56.

MAPA (1994). Métodos Oficiales de Análisis. Tomo III. Servicio de Publicaciones del Ministerio de Agricultura, Pesca y Alimentación, Madrid, España.

Mata, G.R. \& Gaitán-Hernández, R. (1995). Cultivo de Pleurotus en hojas de caña de azúcar. Rev Mex Mic 11: 17-22.

Medina, E., Paredes, C., Pérez-Murcia, M.D., Bustamante, M.A. \& Moral, R. (2009). Spent mushroom substrates as component of growing media for germination and growth of horticultural plants. Bioresour Technol 100: 4.227-4.232.

Nombela, G. \& Bello, A. (1983). Modificaciones al método de extracción de nematodos fitoparásitos por centrifugación en azúcar. Bol Serv Plagas 9: 183-189.

Ozcelik, E. \& Peksen, A. (2007). Hazelnut husk as a substrate for the cultivation of shiitake mushroom (Lentinula edodes). Bioresour Technol 98: 2.6522.658 .

Pardo, J., Pardo, A., Valero, F.A., de Juan, J.A. \& Pardo, J.E. (2003). Evaluación de diferentes combinaciones de sustratos lignocelulósicos y variedades comerciales del hongo basidiomacromiceto Pleurotus ostreatus (Jacq. ex Fr.) Kummer. Actas de Horticultura $\mathrm{n}^{\mathrm{o}}$ 39. X Congreso Nacional de Ciencias Hortícolas, Pontevedra, España.

Pardo, A., Perona, M.A. \& Pardo, J. (2005a). Utilización de raspón de uva en la elaboración de sustratos específicos para el cultivo de Pleurotus ostreatus (Jacq. ex Fr.) Kummer. ITEA 101: 59-69.

Pardo, A., Perona, M.A. \& Pardo, J. (2005b). Evaluación de nuevos materiales en la elaboración de sustratos específicos para el cultivo de Pleurotus ostreatus (Jacq. ex Fr.) Kummer. Cuadernos Fitopal 85: 77-83.

Pardo, A., Perona, M.A. \& Pardo, J. (2007). Nuevos materiales y tratamientos en la elaboración de sustratos para cultivo de Pleurotus ostreatus (Jacq. ex Fr.) Kummer. Cuadernos Fitopal 91: 7-13.

Pardo, A., Pardo, J.E., Picornell, M.R. \& de Juan, J.A. (2009). Suplementación de sustratos degradados por el cultivo de Pleurotus ostreatus (Jacq.) P. Kumm. Resumen de las Actas del VI Congreso Ibérico de Ciencias Hortícolas, La Rioja, España.

Pardo, J., \& López Mondéjar, C. (2004) Aprovechamiento del alperujo de la industria de aceite de oliva para la producción de hongos comestibles. En: Diputación Provincial de Cuenca (Eds.), Actas de las III Jornadas Técnicas del champiñón y otros hongos comestibles en Castilla La Mancha, 69-115. Iniesta, Cuenca, España.

Pathak, H., Jain, N., Bhatia, A., Mohanty, S. \& Gupta, N. (2009). Global warming mitigation potential of biogas plants in India, Environ Monit Assess 157: 407-418. Doi: 10.1007/s10661-008-0545-6

Patra, A.K. \& Pani, B.K. (1995). Evaluation of banana leaf as a new alternate substrate to paddy straw for oyster mushroom cultivation. J Phytol Res 8: 145148.

Pérez, M.R. \& Mata, G. (2005). Cultivo y selección de cepas de Pleurotus ostreatus y $P$. pulmonarius en viruta de pino: obtención de nuevas cepas y evaluación de su producción. Rev Mex Mic 20: 5359.

Philippoussis, A., Zervakis, G. \& Diamantopoulou, P. (2001). Bioconversion of lignocellulosic wastes through the cultivation of the edible mushrooms Agrocybe aegerita, Volvariella volvacea and Pleurotus spp. World J Microb Biot 17: 191-200. Doi: 10.1023/A:1016685530312

Philippoussis, A., Diamantopoulou, P. \& Zervakis, G. (2002). Monitoring of mycelium growth and fructification of Lentinula edodes on several lignocellulosic residues. In: Sánchez, J.E., Huerta, G. y Montiel, E. (Eds.), Mushroom Biology and Mushroom Products, 279-287. UAEM, Cuernavaca, México.

Philippoussis, A., Diamantopoulou, P. \& Zervakis, G. (2003). Correlation of the properties of several lignocellulosic substrates to the crop performance 
of the shiitake mushroom Lentinula edodes. World J Microb Biot 19: 551-557. Doi: 10.1023/A:1025100731410

Picornell, M.R., de Juan, J.A. \& Pardo, A. (2010). Reutilización de sustratos postcultivo de hongos comestibles en el cultivo de Pleurotus ostreatus (Jacq.) P. Kumm. Tesis Doctoral. Escuela Técnica Superior de Ingenieros Agrónomos de Albacete, Universidad de Castilla - La Mancha, España.

Raymond, D.A., Varoney, R.P. \& Chong, C. (1997). Characteristics of composts derived from waxed corrugated cardboard. Compost Sci Util 5: 60-70. Doi: 10.1080/1065657X.1997.10701887

Salmones, D., Gaitán-Hernández, R., Pérez, R. \& Guzmán, G. (1997). Estudio sobre el género Pleurotus VIII. Interacción entre cruzamiento micelial y productividad. Rev Iberoam Micol 14: 173-176.

Sánchez, J.E., Orozco, G.M., Hernández, D., Nieto, M.G. \& Márquez, F.J. (2006). Capacidad del género Pleurotus para la degradación del insecticida endosulfán. El Cromosoma. Boletín del Colegio de Biotecnólogos de Chiapas 2: 31-120.

Shin, G.G., Meguro, S. \& Kawachi, S. (1997). The active constituent in yeast extract for fruit body formation of Lentinula edodes. Can J Microbiol 43: 1.202-1.204.

Stewart, B.A. \& Meek, B.D. (1977). Soluble salt considerations with waste application. In: soils for management of organic wastes and wastewaters (L.F. Elliott and F.J. Stevenson, Eds.). Soil Science Society of America, Madison, Wisconsin, USA. pp 219-232.
Szmidt, R.A.K. (1994). Recycling of spent mushroom substrates by aerobic composting to produce novel horticultural substrates. Compost Sci Util 2: 63-72. Doi: 10.1080/1065657X.1994.10757936

Tajbakhsh, J., Abdoli, M.A., Mohammadi Goltapeh, E., Alahdadi, I. \& Malakouti, M.J. (2008). Trend of physico-chemical properties change in recycling spent mushroom compost through vermicomposting by epigeic earthworms Eisenia foetida and E. andrei. J Agric Technol 4: 185-198.

TECATOR (1987). Determination of Kjeldahl Nitrogen Content with the Kjeltec Auto 1030 Analyzer. Tecator Application Note 30/87, Hönagäs, Sweden.

Varnero, M.T., Quiroz, M.S. \& Álvarez, C.H. (2010). Utilización de residuos forestales lignocelulósicos para producción del Hongo Ostra (Pleurotus ostreatus). Inf Tecnol 21: 13-20. Doi: 10.4067/S0718-07642010000200003

Velázquez-Cedeño, M.A., Mata, G. \& Savoie, J.M. (2002). Waste-reducing cultivation of Pleurotus ostreatus and Pleurotus pulmonarius on coffee pulp: changes in the production of some lignocellulolytic enzymes. World J Microb Biot 18: 201-207. Doi: 10.1023/A:1014999616381

Zadrazil, F. (1980). Conversion of different plant wastes into feed by basidiomycetes. Eur J Appl Microb Biot 9: 243-248. Doi: 10.1007/BF00504491

Zeng-Chin, L., Chiu-Yeh, W., Zheng-Liang, S. \& ShouLiang, C. (2009). Utilization of grass plant for cultivation of Pleurotus citrinopileatus. Int Biodeter Biodegr 63: 509-514. Doi: 10.1016/j.ibiod.2008.12.006 